\title{
PENGARUH MODEL PEMBELAJARAN TUTOR SEBAYA TERHADAP KEYAKINAN DIRI DALAM BELAJAR MATEMATIKA SISWA KELAS VIII SMP NEGERI 3 MELAYA
}

\author{
M. A. P. Yoga Wisudawati, I. M. Candiasa, I. P. Pasek Suryawan \\ Jurusan Pendidikan Matematika Universitas Pendidikan Ganesha \\ Singaraja, Indonesia \\ e-mail: masayu672@gmai.com , candiasaimade@yahoo.co.id ,pasek.suryawan@yahoo.co.id
}

\begin{abstract}
ABSTRAK
Penelitian ini bertujuan untuk mengetahui apakah keyakinan diri dalam belajar matematika siswa yang mengikuti pembelajaran tutor sebaya lebih tinggi dari pada keyakinan diri dalam belajar matematika siswa yang mengikuti pembelajaran konvensional. Penelitian ini dikategorikan sebagai eksperimen semu (quasi experiment) dengan desain penelitian post-test only control group design. Populasi penelitian ini adalah seluruh siswa kelas VIII SMP Negeri 3 Melaya semester ganjil tahun ajaran 2017/2018 sebanyak 189 siswa yang terdistribusi ke dalam 5 kelas. Pengambilan sampel dilakukan dengan teknik cluster random sampling dan diperoleh dua kelas yaitu kelas VIII B sebagai kelas eksperimen dan kelas VIII C sebagai kelas kontrol. Data keyakinan diri dalam belajar matematika siswa dikumpulkan dengan menggunakan angket keyakinan diri dalam belajar matematika. Data keyakinan diri dalam belajar matematika dianalisis dengan menggunakan uji Mann-Whitney satu pihak pada taraf signifikan $5 \%$, karena data keyakinan diri dalam belajar siswa kelompok eksperimen tidak berdistribusi normal. Hasil penelitian menunjukkan bahwa keyakinan diri dalam pelajaran matematika siswa kelas VIII SMP Negeri 3 Melaya yang mengikuti pembelajaran dengan model pembelajaran tutor sebaya lebih tinggi daripada keyakinan diri dalam belajar matematika siswa yang mengikuti pembelajaran konvensional. Dengan demikian dapat disimpulkan bahwa model pembelajaran tutor sebaya berpengaruh positif terhadap keyakinan diri dalam belajar matematika siswa.
\end{abstract}

Kata Kunci: $\quad$ Model Pembelajaran Tutor Sebaya, Keyakinan Diri

\begin{abstract}
This study aimed to find out whether the self-efficacy of students who followed peer tutor learning in learning Mathematics is higher than self-efficacy of students who followed conventional learning. This study was categorized as a quasi-experiment with post-test only controls group design. The population of this research was all students of class VIII SMP Negeri 3 Melaya in first semester of academic year 2017/2018 with 189 students who were distributed into 5 classes. The sampling of this research was conducted by cluster random sampling technique and obtained two classes that were VIII B class as experiment class and VIII C class as control class. Students' self-efficacy data in learning mathematics was collected by using self-efficacy questionnaire in learning Mathematics. Furthermore, the data were analyzed by using a one-party $U$ Mann-Whitney test at $5 \%$ of significant level, because the data of selfefficacy in students' learning experimental group is not normally distributed. The results showed that the self-efficacy of VIII grade students of SMP Negeri 3 Melaya who followed peer tutor learning model in learning mathematics was higher than self-efficacy of students who followed conventional learning. Therefore, it can be conclude that the peer tutor learning model has a positive effect on students' selfefficacy in learning Mathematics.
\end{abstract}

Keywords: Peer tutor learning model, Self-efficacy in learning Mathematics

\section{PENDAHULUAN}

Matematika merupakan salah satu ilmu pendidikan sekolah yang memiliki kontribusi penting dalam perkembangan ilmu pengetahuan dan teknologi. Dalam perkembangannya, konsep matematika banyak digunakan dalam menyelesaikan masalah pada kehidupan sehari-hari. Selain itu menurut Soedaji (2004), pendidikan matematika memiliki tujuan pembentukan karakter atau watak pesta 
didik seperti berpikir logis, analitis, sistematis, serta berpikir kritis.

Matematika dikenal sebagai ilmu dasar yang terstruktur, sehingga pembelajaran matematika di setiap jenjangnya memerlukan perhatian yang lebih. Keberhasilan siswa dalam proses belajar matematika tidak hanya dipengaruhi tingkat kecerdasan intelektual (intelegensi quotient). Kemampuan kognitif yang dimiliki seorang siswa haruslah diimbangi dengan kemampuan emosional yang baik pula. Sejalan dengan hal tersebut Goleman (2001) berpendapat bahwa kecerdasan intelektual (IQ) hanya menyumbang $20 \%$ bagi terbentuknya individu yang sukses dalam menghadapi tantangan, sedangkan $80 \%$ sisanya merupakan sumbangan faktor lain. Faktor penunjang lain yang dimaksud seperti kemauan, motivasi, keyakinan diri, maupun kecemasan yang dimiliki setiap individu.

Belajar matematika merupakan proses psikologis berupa kegiatan aktif dalam diri seseorang untuk memahami atau menguasai materi matematika. Pembelajaran matematika adalah pembelajaran yang dibangun berdasarkan pengetahuan awal yang dimiliki siswa dengan menekankan pembentukan konsep yang diperoleh dari hasil kontruksi dengan kemampuan sendiri. Hal ini membuat siswa harus yakin terhadap kemampuan diri sendiri baik terhadap kemampuan awal matematika maupun terhadap keterkaitan kemampuan awal untuk membentuk pengetahuan matematika baru yang sedang atau akan dipelajarinya. Dengan kata lain siswa harus memiliki rasa keyakinan diri dalam belajar matematika.

$$
\text { Keyakinan diri (self-efficacy) }
$$

mengacu pada persepsi tentang kemampuan individu untuk mengorganisasi dan mengimplementasikan tindakan untuk menampilkan kecakapan tertentu (Bandura, 1986). Keyakinan diri juga berarti rasa memiliki kemampuan untuk berhasil dan sukses. Individu dengan keyakinan diri yang tinggi dapat mengambil tindakan yang tepat dan tegas melalui kontrol diri dan pola pikir yang optimis sesuai dengan kompetensi dan minat yang dimilikinya untuk mencapai tujuan. Lebih lanjut Sivandani, Koohbarani, dan Vahidi (2013) menyatakan keyakinan diri adalah keyakinan tentang kemampuan diri sendiri untuk menghasilkan kinerja yang maksimal yang dapat memengaruhi kehidupan mereka.

Keyakinan diri individu dapat dilihat atau diukur melalui tiga dimensi keyakinan diri yaitu; (1) dimensi tingkat (level) mengukur keyakinan diri individu dalam mengerjakan suatu tugas atau menyelesaikan masalah, individu dengan keyakinan diri yang tinggi cenderung memilih tugas dengan tingkat kesukaran yang sesuai dengan kemampuannya; (2) dimensi keluasan (generality) mengukur keyakinan diri individu dalam penguasaan pengetahuan yang diperlukan dalam menyelesaikan masalah, individu dengan keyakinan diri yang tinggi cenderung menguasai beberapa bidang sekaligus; (3) dimensi kekuatan (strengh) mengukur keyakinan diri individu dalam kemampuan untuk bekerja keras, individu dengan keyakinan diri yang tinggi cenderung memiliki ketahanan bekerja keras yang lebih tinggi dalam mencapai hasil yang sesuai bahkan ketika mengalami kegagalan berulang.

Peningkatan keberhasilan proses belajar matematika juga dipengaruhi oleh pemilihan model pembelajaran. Pemilihan model pembelajaran dipandang perlu dan penting untuk menunjang proses kegiatan pembelajaran agar siswa dapat belajar dengan baik dan mendapat hasil yang baik. Model pembelajaran yang diterapkan dalam proses pembelajaran haruslah dapat secara efektif dan efisien meningkatkan prestasi belajar siswa dengan memperhatikan karakteristik siswa serta faktor-faktor lain yang mempengaruhinya. Model pembelajaran tutor sebaya merupakan salah satu model yang dapat ditawarkan sebagai solusi peningkatan proses belajar siswa dengan membantun proses pembentukan serta peningkatan keyakinan diri dalam belajar 
matematika. Model pembelajaran tutor sebaya merupakan model pembelajaran yang dalam implementasinya siswa belajar dengan membentuk kelompok kecil yang heterogen secara karakteristik kemampuan, setiap kelompok yang dibentuk terdiri dari satu tutor yang bertugas memberikan bantuan belajar pada siswa yang mengalami kesulitan belajar didalam kelompok.

Model pembelajaran tutor sebaya memiliki lima tahapan kegiatan pembelajaran yang diduga dapat meningkatkan rasa keyakinan diri siswa yaitu; (1) tahap determining merupakan tahap pemilihan dan penugasan tutor, dalam tahap ini dapat diukur keyakinan diri siswa tentang pemahaman materi pembelajaran dan kekuatan keyakinannya sehingga dapat membantu teman sebaya dalam menghadapi kesulitan belajar; (2) tahapan tutoring merupakan tahap pemberian bimbingan belajar oleh tutor sebaya, dalam tahap ini keyakinan diri siswa selain tutor dapat diukur mengenai pemahaman materi untuk menyelesaikan tugas, pemahaman materi untuk penambahan keluasan pengetahuan; (3) tahapan exercising merupakan tahap latihan soal untuk mengkonstruksi pengetahuan maupun pemantapan pengetahuan, pada tahap ini dapat diukur keyakinan diri siswa mengenai tingkat penyelesaian tugas, dan ketahanan keyakinannya untuk terus mencoba mencapai hasil yang diharapkan; (4) tahapan presenting merupakan tahap penyampaian kembali pemahaman siswa terhadap materi, pada tahap ini keyakinan diri siswa selain tutor diukur mengenai pemahaman materi pembelajaran dan kekuatan keyakinannya sehingga dapat menyampaikan pendapat; (5) tahapan evaluating merupakan tahap pemberian umpan balik terhadap kesimpulan pembelajaran serta tes pemahaman materi pembelajaran. Pada tahap ini keyakinan diri diukur tentang pemahaman materi pembelajaran dalam menyelesaikan tugas.

Penerapan model pembelajaran tutor sebaya juga dapat membentuk interaksi yang baik antar peserta didik, sebagai tutor siswa dapat memperkuat pemahaman konsep yang sedang dibahas melatih rasa tanggung jawab, sikap otonomi, proaktif, luwes, mudah bekerja sama, dan kontrol diri sebagai awal rasa keyakinan diri. Silberman (2009) menjelaskan bahwa pembelajaran dengan tutor sebaya adalah pembelajaran yang memberikan kesempatan pada seseorang atau beberapa orang peserta didik yang dianggap mampu untuk memberikan pengajaran pada peserta didik lainnya. Siswa selain sebagai tutor dapat memberikan penguatan berupa persuasi verbal, memberikan arahan menuju keberhasilan belajar sesuai pengalamannya serta penguatan dalam penumbuhan rasa keyakinan diri. Dan untuk siswa sebagai tutor dapat menambah pengalaman kesuksesan serta kemantapan. Hal diatas merupakansumber sumber penting dalam menumbuhkan rasa keyakinan diri siswa dalam proses belajar (Bandura, 1995). Dari hal tersebut diduga bahwa model pembelajaran tutor sebaya dapat meningkatkan rasa keyakinan diri siswa dalam belajar.

Beberapa hasil penelitian pun menunjukkan hasil yang positif terhadap penggunaan model pembelajaran tutor sebaya. Abdul Kholid (2005) dalam penelitiannya menyatakan dukungan teman sebaya berpengaruh terhadap rasa keyakinan diri siswa dalam keterlibatan siswa pada kegiatan sekolah. Hasnawati Nurdin (2012) dalam penelitiannya menyatakan bahwa penerapan langkahlangkah pembelajaran tutor sebaya dapat meningkatkan keyakinan diri siswa dalam belajar kimia.

Berdasarkan uraian diatas, menunjukkan bahwa model pembelajaran tutor sebaya merupakan model pembelajaran inovatif yang diharapkan mampu meningkatkan keyakinan diri siswa dalam belajar, serta belum adanya penelitian yang mengkaji lebih dalam tentang pengaruh model pembelajaran tutor sebaya terhadap keyakinan diri dalam belajar matematika siswa, sehingga penulis tertarik melakukan penelitian yang berjudul "Pengaruh Model 
Pembelajaran Tutor Sebaya Terhadap Keyakinan Diri dalam Belajar Matematika Siswa Kelas VIII SMP Negeri 3 Melaya". METODE

Penelitian ini merupakan quasi eksperimen (eksperimen semu). Penelitian ini dikatakan eksperimen semu karena memiliki tujuan untuk mengetahui apakah keyakinan diri dalam belajar matematika siswa yang mengikuti pembelajaran dengan model pembelajaran tutor sebaya lebih tinggi dari siswa yang mengikuti pembelajaran konvensional. Sedangkan faktor-faktor lain yang dapat mempengaruhi keyakinan diri dalam belajar matematika tidak dikaji pada penelitian ini. Populasi dalam penelitian ini adalah seluruh siswa kelas VIII SMP Negeri 3 Melaya tahun ajaran 2017/2018. Banyaknya populasi dalam penelitian ini adalah 189 orang siswa yang tersebar kedalam kelas yaitu VIII A, VIII B, VIII C, VIII D, VIII E. Pemilihan sampel pada penelitian ini tidak melalui pengacakan individu, karena tidak bisa mengubah kelas yang sudah ada. Pengambilan sampel dilakukan secara acak untuk menentukan dua kelas yang akan digunakan sebagai sampel penelitian dilakukan dengan teknik cluster random sampling yang pemilihannya mengacu pada kelompok bukan individu. Penentuan kelas sampel dari 5 kelas populasi dilakukan secara random dengan cara pengundian. Pengundian dilakukan dengan asumsi bahwa setiap kelas memiliki kemampuan dan kesempatan yang sama untuk menjadi sampel penelitian.

Penelitian ini bertujuan untuk menyelidiki pengaruh model pembelajaran tutor sebaya terhadap keyakinan diri dalam belajar matematika siswa kelas VIII SMP Negeri 3 Banjar. Rancangan eksperimen yang digunakan dalam penelitian ini adalah Post-Test Only Control Group Design, di mana kelompok kontrol adalah kelompok dengan pembelajaran konvensional, sedangkan kelompok eksperimen adalah kelompok yang dibelajarkan dengan model pembelajaran tutor sebaya. Penelitian ini melibatkan variabel bebas (independent variable) dan variabel terikat (dependent variable) yang dijelaskan sebagai berikut:
1. Variabel bebas (independen variable)
Variabel bebas dalam penelitian ini adalah model pembelajaran tutor sebaya pada kelompok eksperimen dan pembelajaran konvensional pada kelompok kontrol.

2. Variable terikat (dependen variable) Variabel terikat dalam penelitian ini alah keyakinan diri dalam belajar matematika.

Data yang diperlukan dalam penelitian ini adalah data keyakinan diri dalam belajar matematika, sehingga diperlukan instrumeny yang sesuai dalam pengumpulan informasi tersebut. Suharsaputra (2012) mengatakan bahwa instrument merupakan alat ukur yang digunakan untuk mengumpulkan informasi tentang variasi karakteristik variable secara empirik, oleh karena itu instrument penelitian harus memenuhi kriteria valid dan reliable. Sebelum dilaksanakan uji coba instrument yaitu untuk menentukan validasi dan reliabilitas instrument, instrument tersebut dikonsultasikan terlebih dahulu dengan dosen pembimbing dan guru matematika kelas VIII SMP Negeri 3 Melaya, hal ini dilakukan untuk mengetahui apakah intrumen yang dibuat sudah sesuai.

Uji coba instrumen dilakukan untuk mendapat gambaran secara empirik apakah instrumen tersebut layak digunakan sebagai instrumen penelitian. Candiasa (2010a: 21) menyatakan "Instrumen disebut valid apabila benarbenar mampu mengukur apa yang semestinya diukur dengan instrumen tersebut". Sugiyono (2010: 173) menyatakan "Instrumen yang reliabel adalah instrumen yang bila digunakan beberapa kali untuk mengukur obyek yang sama, akan menghasilkan data yang sama".

Instrumen yang digunakan dalam penelitian ini berupa non tes yaitu angket keyakinan diri dalam belajar matematika yang sebelumnya melalui uji kelayakan berupa uji validitas dan uji reliabilitas. 
Pengujian validitas instrument dilakukan dengan menggunakan formulasi korelasi pearson product momen. Koefisien korelasi Product Moment $\left(r_{x y}\right)$ dibandingkan dengan harga $r_{\text {tabel }}$ untuk mengetahui validitas masing-masing butir. Jika $r_{x y}>r_{\text {tabel, }}$ maka butir bersangkutan dinyatakan valid. Jika $r_{x y} \leq r_{\text {tabel, }}$, maka butir bersangkutan dinyatakan tidak valid (Candiasa, 2010a). Dari hasil analisis data uji coba angket, diperoleh bahwa dari 40 pernyataan yang diujikan terdapat 36 pernyataan yang valid yang selanjutnya digunakan sebagai angket keyakinan diri dalam belajar matematika siswa. Angket keyakinan diri tersebut kemudian uji reliabilitasnya . dari pengujian reliabilitas angket keyakinan diri tersebut, diperoleh bahwa realiabilitas angket adalah 0,948. Dari kriteria yang telah ditetapkan maka derajad reliabilitas angket keyakinan diri dalam belajar matematika siswa tersebut dikatakan reliable dengan derajad reliabilitas sangat tinggi.

Pengujian reliabilitas instrumen menggunakan formula Alpha Cronbach. Pernyataa-pernyataan yang digunakan dalam instrumen keyakinan diri adalah pernyataan-pernyataan yang valid dan menjedikan intrumen yang dibentuk memiliki derajad reliabilitas minimal sedang. Setelah instrumen keyakian diri dalam belajar matematika memenuhi syarat valid dan reliabel. Instumen tersebut dapat langsung digunakan untuk mengumpulkan data skor keyakinan diri dalam belajar.

Sebelum dilaksanakan pengujian untuk memperoleh simpulan, data skor yang diperoleh harus melalui alalisis prasyarat uji hipotesis yaitu uji notmalitas dan hamogenitas. Dalam penelitian ini pengujian normalitas untuk skor keyakinan diri dalam belajar matematika siswa dengan menggunakan uji Liliefors. Sedangkan uji homogenitas varian untuk kedua kelompok dilakukan dengan menggunakan uji $F$. Setelah mengetahui hasil uji prasyarat hipotesis barulah ditentukan uji hipotesis yang digunakan.

\section{HASIL PENELITIAN}

motivasi belajar siswa kelompok eksperimen dan kelompok control disajikan pada tabel berikut, yaitu simpangan (simpangan baku dan varians). Rekapitulasi hasil perhitungan deskriptif dapat disajikan seperti tabel 1 berikut:

Tabel 01. Hasil Analisis skor keyakinan diri dalam belajar matematika

\begin{tabular}{|c|c|c|}
\cline { 2 - 3 } \multicolumn{1}{c|}{} & \multicolumn{2}{c|}{ Kelompok } \\
\cline { 2 - 3 } \multicolumn{1}{c|}{} & Eksperimen & Kontrol \\
\hline $\mathrm{n}$ & 38 & 38 \\
\hline$N_{\max }$ & 148 & 140 \\
\hline$N_{\min }$ & 84 & 67 \\
\hline $\bar{Y}_{1}$ & 110.76 & 99.74 \\
\hline$S_{1}^{2}$ & 188.78 & 252.42 \\
\hline$S_{1}$ & 13.74 & 15.89 \\
\hline
\end{tabular}

Pada tabel terlihat bahwa rata-rata skor keyakinan diri dalam belajar matematika siswa kelompok eksperimen yang mengikuti pelajaran dengan model pembelajaran tutor sebaya lebih tinggi daripada rata-rata skor keyakinan diri dalam belajar matematika siswa kelompok kontrol yang mengikuti pelajaran dengan pembelajaran konvensional.

Untuk selanjutnya akan dilakukan uji formalitas untuk uji homogenitas dan uji normalitas data.

Tabel 02. Hasil Uji Normalitas skor keyakinan diri dalam belajar matematika 


\begin{tabular}{|c|c|c|}
\hline Kelompok Sampel & $L_{\text {hitung }}$ & $L_{\text {tabel }}$ \\
\hline Eksperimen & 0,1673 & 0,1421 \\
\hline Kontrol & 0,0741 & 0,1421 \\
\hline
\end{tabular}

Dari tabel hasil uji normalitas data keyakian diri dalam belajar matematika siswa pada yang ditampilkan pada tabel 02 dapat disimpulkan, kelompok eksperimen tidak berdistribusi normal karena $L_{\text {hitung }}>$ $L_{\text {tabel }(38,0.05)}$ yang mengakibatkan hasil pengujian tolak hipotesis nol. Sedangkan hasil pengujian normalitas data pada kelompok kontrol diperoleh $L_{\text {hitung }}<$ $L_{\text {tabel(38,0.05) }}$ maka hasil pengujian terima hipotesis nol yang berarti bahwa data skor angket kelompok kontrol berdistribusi normal. Sedangkan hasil uji homogenitas varian kedua kelompok sampel diperoleh nilai $F_{\text {hitung }}=1.33709$ sedangkan nilai $F_{\text {tabel }}$ untuk taraf signifikan $5 \%$ dengan derajad kebebasan pembilang $n_{1}-1=35$ untuk dan derajad kebebasan untuk penyebut $n_{2}-1=35$ adalah 1,765. Dari data tersebut $F_{\text {hitung }}<F_{\text {tabel }}$ sehingga kedua kelompok tersebut memiliki varians yang homogen.

Oleh karena data sampel kelompok eksperimen tidak berdistribusi normal sedangkan kedua kelompok sampel memiliki varians yang homogen, pengujian dilanjutkan dengan pengujian hipotesis penelitian yaitu menggunakan uji U MannWhitney.

Dari hasil perhitungan diperoleh nilai $Z_{\text {hitung }}$ $=3,02$, kriteria pengujian adalah tolak $H_{0}$ jika $Z \geq Z_{a}$. Untuk pengujian satu pihak taraf signifikan yang digunakan $\alpha=0,025$ dengan $Z_{0,025}=1,96$, sehingga $Z \geq Z_{a}$. Ini berarti bahwa keyakinan diri dalam belajar matematika siswa yang mengikuti pembelajaran dengan model pembelajaran tutor sebaya lebih tinggi dari pada keyakinan diri dalam belajar matematika siswa yang mengikuti pembelajaran konvensional.

Berdasarkan hasil analisis terhadap skor keyakinan diri dalam belajar matematika, dapat dikatakan bahwa keyakinan diri dalam belajar matematika siswa yang mengikuti pembelajaran dengan model pembelajaran tutor sebaya lebih tinggi dari keyakinan diri dalam belajar matematika siswa yang mengikuti pembelajaran konvensional. Dengan kata lain model pembelajaran tutor sebaya berpengaruh positif terhadap keyakinan diri dalam belajar matematika siswa.

Hasil penelitian ini sejalan dengan hasil penelitian Abdul Kholid (2015) yang menyatakan bahwa dukungan teman sebaya merupakan sumber atas dukungan sosial yang berpengaruh terhadap rasa keyakinan diri pada usia remaja. Berbeda dengan pendapat tersebut Setiana (2015) dalam penelitiannya menyatakan keterkaitan pembelajaran menggunakan tutor sebaya dengan keyakinan diri siswa tidak signifikan mengingat pengaruh faktor lingkungan belajar.

Keyakinan diri dalam belajar matematika siswa yang mengikuti pembelajaran dengan model pembelajaran tutor sebaya lebih tinggi dari keyakinan diri dalam belajar matematika siswa yang mengikuti pembelajaran konvensional pada penelitian ini, terjadi karena perbedaan perlakuan yang diberikan di masing-masing kelompok. Pada kelompok eksperimen, siswa dibelajarkan dengan menggunakan model pembelajaran tutor sebaya. Selama proses pembelajaran berlangsung siswa lebih tertarik dan termotivasi untuk aktif dalam mengikuti pembelajaran. Selain itu siswa lebih terorganisir karena adanya tutor yang diberikan kesempatan menilai keaktifan temannya dalam belajar

Pembelajaran dengan model pembelajaran tutor sebaya memungkinkan siswa untuk leluasa bertanya dan menanggapi masalah-masalah dalam belajar, karena berada dalam kelompok diskusi yang didampingi oleh tutor sebaya yang tidak lain adalah teman sekelas yang 
dianggap mampu dan memiliki pengalaman kesuksesan dalam belajar. Hal ini terlihat pada proses pembelajaran di kelas yaitu siswa lebih aktif dalam menyelesaikan masalah-masalah yang diberikan dalam LKS dengan bantuan tutor sebaya. Dengan sedikit bimbingan dari guru tiap-tiap kelompok siap untuk menyampaikan penyelesaian LKS sesuai tujuan pembelajaran.

Penerapan model pembelajaran tutor sebaya dimulai dengan prapembelajaran dikelas. Peserta prapembelajaran terdiri dari 15 orang siswa calon tutor yang dipilih melalui proses pemilihan tutor. Siswa calon tutor diberikan rangkuman materi yang harus dipahami selama proses pembelajaran nanti. Pada proses pra-pembelajaran dikelas, siswa calon tutor melakukan diskusi terbuka bersama guru mengenai materi serta permasalahan dalam menjelaskan materi. Pada pra-pembelajaran di kelas juga dijelaskan tugas-tugas tutor dan sistem penentuan tutor baik secara penugasan, giliran, maupun volunteer. Prapembelajaran dikelas ini merupakan bagian tahapan penentuan (determining) pada tahapan model pembelajaran tutor sebaya. Pada pra-pembelajaran ini siswa sudah mendapatkan sumber keyakinan diri berupa pengalaman akan kesuksesan belajar matematika, serta persuasi verbal dari guru saat memberikan pengakuan bahwa mereka mampu menjadi tutor.

Penerapan model pembelajaran tutor sebaya di dalam kelas dimulai dengan tahap determining yaitu pembagian kelompok dan penentuan tutor sebaya di masing-masing kelompok. Pada tahap ini tutor terpilih melalui tiga cara yaitu; (1) penunjukan pada pertemuan ke-1 dan ke2; (2) giliran pada pertemuan ke-3 s.d. ke6; (3) volunteer pada pertemuan ke-7 dan ke-8. Siswa dibagi dalam lima kelompok yang tiap kelompok terdiri satu tutor. Pada tahap ini juga diberikan apersepsi dan motivasi belajar oleh guru. Hal ini bertujuan untuk meningkatkan pola pikir yang optimis sesuai dengan kompetensi dan minat belajar matematika sebagai dasar rasa keyakinan diri dalam belajar.
Selanjutnya tahap tutoring, siswa sebagai tutor mengambil dan membagikan ringkasan materi dan LKS dari guru. Siswa selain tutor mengamati dan mengumpulkan informasi melalui ringkasan materi serta buku sumber yang ada untuk memahami materi yang dibelajarkan. Pada tahap ini siswa selain tutor dengan leluasa belajar baik bertanya maupun menanggapi masalah belajar dalam kelompok yang dibantu oleh tutor sebaya. Pada tahap ini siswa selain tutor membangun keyakinan diri melali penguatan dan pengalaman kesuksesan siswa lain yaitu tutor. Sehingga siswa secara keseluruhan dapat membangun dan meningkatkan rasa keyakinan diri dalam belajar matematikanya.

Selain itu pemberian rangkuman materi oleh guru, dapat menjadi acuan dasar dari materi yang akan dipelajari agar konsep yang dipahami siswa tidak keliru dan memudahkan siswa dalam memahami materi. Dengan rangkuman materi ini tutor dapat memahami konsep dasar dan cara menjelaskan materi dengan terstruktur sesuai dengan tujuan pembelajaran. Siswa selain tutor dapat mencoba menyelesaikan lebih banyak soal maupun penerapan dari materi yang dipelajari secara mandiri sesuai rangkuman materi. Dengan demikian, siswa dapat mengkonstruksi pengetahuan sesuai dengan apa yang ia pahami tidak terbatas pada contoh dan latihan yang diberikan pada LKS oleh guru. Berbeda dengan kelompok eksperimen pada kelompok kontrol yaitu kelompok siswa yang mengikuti pembelajaran konvensional yang belajar melalui kelompok kecil tanpa tutor, masalah belajar yang dihadapi siswa dalam kelompok belum tentu mendapat solusi dalam kelompok. Pada kelompok kontrol cenderung malu bertanya ada guru dan juga pada teman dalam kelompok karena tidak ada tanggung jawab yang jelas siapa yang harus menjelaskan materi yang tidak siswa pahami. Hal ini mengakibatkan kesenjangan rasa keyakinan diri dalam belajar matematika. siswa yang berani bertanya akan terlihat sangat aktif di kelas sedangkan yang malu 
bertanya akan susah untuk mengatasi masalah belajarnya. Selain itu siswa yang telah memiliki keyakinan diri cenderung meningkat atau menurun, sedangkan yang tidak memiliki keyakinan diri akan sulit membangun rasa keyakinan diri dalam belajar matematika.

Tahap pembelajaran selanjutnya pada kelompok siswa yang mengikuti pembelajaran dengan model pembelajaran tutor sebaya adalah exercising. Pada tahap ini siswa selain tutor diberikan kesempatan mengerjakan soal dalam LKS secara individu oleh tutor. Selanjutnya jika dirasa sudah tidak mampu mengerjakan soal barulah tutor membimbing siswa dalam kelompok untuk menyelesaikan LKS. Tahap exercising ini diakhiri dengan membuat rangkuman kelompok tentang materi dan penyelesaian soal pada LKS.

Pada tahap presenting, siswa selain tutor diminta menyampaikan rangkuman hasil diskusi kelompok di depan kelas yang dilanjutkan dengan diskusi bersama. Siswa selain tutor diberikan kesempatan bertanya maupun menanggapi pertanyaan dan penyampaian materi dari kelompok penyaji yang kemudian dilanjutkan dengan penyampaian informasi atau konfirmasi dari tutor. Pada proses diskusi ini juga tampak anggota-anggota kelompok selain kelompok penyaji lebih aktif dalam menanggapi pendapat yang disajikan serta menjawab pertanyaan dari guru. Hal ini menunjukkan bahwa pembelajaran yang diterapkan telah mengakomodasi ha-hal yang seharusnya menjadi perhatian dalam pelajaran matematika, yaitu antusiasme dalam menerima pengetahuan dan penyampaian kembali dengan pemahaman sendiri guna mengkonfirmasi kesesuaian tujuan belajar.

Pembelajaran tutor sebaya tidak hanya memberikan kesempatan pada tutor dalam melatih menyampaikan dan menjelaskan materi sesuai dengan pemahaman sendiri, melalui tahap persentasi (presenting) siswa selai tutor dapat menyampaikan informasi, pendapat, dan sanggahan tentang topik materi yang dibelajarkan. Interaksi yang terjadi pada tahap ini bermuara pada kesamaan pola pikir dan pemahaman materi sesuai tujuan pembelajaran.

Pada tahap evaluating, didahului dengan penyampaian informasi, tanggapan, serta konfirmasi dari guru mengenai materi agar sesuai dengan konsep materi dan tujuan pembelajaran. Selanjutnya guru membimbing siswa membuat rangkuman pembelajaran dan diakhiri dengan pemberian tes evaluasi pada seluruh siswa yang dikerjakan secara individu.

Berdasarkan hasil pengamatan selama kegiatan penelitian, proses pembelajaran dengan model pembelajaran tutor sebaya ini memperlihatkan keyakinan diri dalam belajar matematika. siswa semakin berani bertanya, menanggapi, maupun menuliskan dan menjelaskan penyelesaian soal di papan tulis. Hal ini dikarenakan lebih banyaknya dukungan untuk merasa yakin terhadap kemampuan diri yang didapat baik oleh guru maupun oleh tutor sebaya.

Hasil pengamatan ini juga didukung oleh hasil skor keyakinan diri dalam belajar matematika siswa, yang menunjukkan bahwa kelompok siswa yang mengikuti pembelajaran dengan model pembelajaran tutor sebaya memiliki keyakinan diri yang lebih tinggi dari kelompok siswa yang mengikuti pembelajaran konvensional.

Meskipun secara umum pembelajaran matematika dengan model pembelajaran tutor sebaya dapat dilaksanakan dengan baik, dalam pelaksanaannya juga terdapat beberapa kendala yaitu sebagai berikut: (1) masih ada siswa yang kurang berani mengajukan pertanyaan, mengemukakan pendapat, dan menanggapi jawaban temannya dalam kelompok. Hal ini diantisipasi dengan penunjukan siswa secara langsung oleh guru untuk mencoba menjawab soal serta bertanya langsung pada siswa apakah materi yang disampaikan sudah dipahami dengan penugasan penyampaian hasil diskusi pada guru. (2) siswa masih bingung cara menyampaikan atau menjelaskan hasil diskusi kelompok di depan kelas. Upaya yang dapat dilakukan dengan 
memberikan arahan singkat pada kelompok penyaji sehingga seiring waktu, presentasi dapat berjalan sesuai harapan. (3) siswa terkadang merasa bosan karena selalu dihadapkan dengan pembelajaran berkelompok, sehingga diperlukan trik khusus dari guru untuk menyegarkan suasana. Hal ini diantisipasi dengan memberikan selingan berupa pertanyaanpertanyaan atau game yang terkait dengan materi.

Berdasarkan uraian diatas, memberikan gambaran bahwa model pembelajaran tutor sebaya telah mampu memberikan kontribusi positif terhadap keyakinan diri dalam belajar matematika siswa. Oleh karena itu, diharapkan model pembelajaran tutor sebaya dapat dikembangkan secara inovatif dan diterapkan dalam kegiatan pembelajaran guna upaya peningkatan mutu pendidikan khususnya dalam pelajaran matematika.

\section{SIMPULAN DAN SARAN}

Berdasarkan hasil penelitian dan pembahasan, diperoleh temuan bahwa keyakinan diri dalam belajar matematika siswa kelas VIII SMP Negeri 3 Melaya yang mengikuti pembelajaran dengan model pembelajaran tutor sebaya lebih tinggi daripada keyakinan diri dalam belajar matematika siswa kelas VIII SMP Negeri 3 Melaya yang mengikuti pembelajaran konvesional. Temuan ini didukung dengan kenyataan bahwa; (1) siswa yang mengikuti pembelajaran dengan model tutor sebaya lebih aktif untuk menyelesaikan masalah-masalah yang diberikan, dan (2) siswa lebih berani untuk mengkomunikasikan pendapat maupun pernyatan.

Adapun saran yang dapat disampaikan berdasarkan hasil penelitian yang telah dilaksanakan adalah sebagai berikut. (1) Penelitian ini terbatas pada materi koordinat cartesius, aljabar dan fungsi. Bagi para peneliti selanjutnya disarankan untuk melakukan penelitian lebih lanjut tehadap materi matematika yang lain untuk lebih mengetahui pengaruh model pembelajaran tutor sebaya dalam pembelajaran matematika secara lebih mendalam.. (2) Para praktisi pendidikan matematika, khususnya guru, diharapkan menerapkan model pembelajaran tutor sebaya sebagai salah satu alternatif pembelajaran yang berpusat pada siswa mengingat pengaruh positif yang diberikan terhadap keyakinan diri dalam belajar matematika siswa.

\section{DAFTAR PUSTAKA}

Bandura, A. 1986. Self-efficacy in Changing Societies. New York: Cambridge University Press.

Candiasa, I M. 2010a. Pengujian Instrumen Penelitian disertai Aplikasi ITEMAN dan BIGSTEPS. Singaraja: Unit Penerbitan Universitas Pendidikan Ganesha.

Goleman, D. 2001. Kecerdasan Emosional. Jakarta: PT Gramedia Pustaka Utama.

Hasnawati, N. 2012. "Penerapan Metode Tutor Sebaya pada Mata Pelajaran Kimia untuk Meningkatkan SelfEfficacy Siswa Kelas XII Pertanian SMKN 1 Watang Pulu Sidrap". Tersedia pada http://ojs.unm.ac.id/chemica/article /view/622. diakses pada tangga 15 april 2018

Setiana. 2015. Peer Tutoring Dan Program Catch Kaitannya Dengan Self Efficacy. Tersedia pada http://seminar.uny.ac.id/semnasmat ematika/sites/seminar.uny.ac.id. semnasmatematika/files/banner/PM107.pdf (di akses pada tanggal 18 april 2018)

Silberman, M. 2009. 101 Strategi Pembelajaran Aktip. Yogyakarta: Pustaka Insan Mandiri.

Sivandani, A., Koohbadani, S. E.,\& Vahidi. T. 2013. The realation between social support and self-efficacy with academic achievement and school satisfaction among female junior high school student in Birjand. Procedia Social and Behavioral Science 84, 668-673. Tersedia pada 
dttps//www.sciencedirect.com.

diakses pada tanggal 1 Februari 2015

Soedaji, R. dkk. 2004. PMRI dan KBK dalam Era Otonomi. Buletin PMRI Edisi III. Bandung.

Sugiyono. 2010. Metode Penelitian Kuantitatif Kualitatif dan $R \& D$. Bandung: Alfabeta.
Suharsaputra, U. 2012. Metode Penelitian Kuantitatif, Kualitatif, dan Tindakan. Bandung: PT Reflika Aditama

Yaumi, M. 2012. Belajar berbasis multiple intellegeces. Jakarta:ndian rakyat (diakses tanggal 29 Agustus 2016) 